\title{
Makna Simbolik Arsitektur Gereja Santo Cornelius Kelurahan Pangongangan Kecamatan Manguharjo Kota Madiun Jawa Timur
}

\author{
Annisa Tri Rahmawati dan Abraham Nurcahyo*
}

\begin{abstract}
Abstrak
Penelitian ini bertujuan untuk mengetahui makna simbolik arsitektur Gereja Santo Cornelius. Penelitian ini dilakukan di Gereja Katolik Santo Cornelius Kelurahan Pangongangan Kecamatan Manguharjo Kota Madiun. Jenis penelitian yang digunakan yaitu penelitian sejarah, sehingga menggunakan metode sejarah dalam pelaksanaanya. Teknik pengambilan data dengan menggunakan metode wawancara, observasi, dan dokumentasi. Sumber data yang digunakan yaitu sumber data primer dan sumber data sekunder. Teknik keabsahan data yang digunakan adalah analisis data model interaktif.

Gereja Santo Cornelius berdiri tanggal 12 Maret 1899, dibangun dengan memiliki menara dan salib diatasnya. Dinamakan Gereja Santo Cornelius karena Cornelius adalah seorang imam yang bijaksana,saleh dan seorang imam yang penuh kedamaian, keadilan dan kemuliaan Tuhan dengan Mahkota Kemartiran. Kerena hal itulah, umat Katolik menamakan dengan Gereja Santo Cornelius. Tabernakel dilengkapi dengan lampu yang menyala terus sebagai simbol Yesus Kristus Menyala abadi. Itu sebabnya, ketika orang masuk Gereja biasanya didahului dengan pengambilan air suci di depan pintu masuk lalu melakukan tanda salib dan seterusnya bersujud. Posisi menara diletakkan disebelah kiri pintu masuk, memberikan simbol Allah yang melindungi manusia dengan tangan kanan-Nya (apabila dilihat posisi altar adalah posisi dimana Allah hadir dan memandang ke arah masuk umat),dan makna psikologisnya yaitu memberikan rasa aman mengingat manusia selalu merasa lemah di sebelah kiri.
\end{abstract}

Kata Kunci : Simbolik, Arsitektur, Gereja Santo Cornelius

\section{Pendahuluan}

Madiun adalah salah satu wilayah yang berada di propinsi Jawa Timur, yang merupakan daerah bekas jajahan Belanda. Banyak sektor yang dikelola dan dikembangkan oleh Belanda, diantaranya bidang industri, transportasai dan religius.

$$
\text { Beberapa sektor Industri yang }
$$
merupakan peninggalan Belanda, misalnya Industri gula yang tersebar di Karesidenan Madiun seperti Pabrik Gula Rejo Agung, Pabrik Gula Pagotan, Pabrik Gula Kanigoro dan lain sebagainya. Selain itu, Industri kereta api yang mengembangkan sektor transportasi massal yang menghubungkan beberapa daerah di Karesidenan Madiun bertujuan untuk mempermudah koordinasi dengan daerah di luar Kota Madiun.

Banyak bangunan yang bersejarah dan mempunyai makna simbolik dan arsitektur yang unik dan menarik. Bangunan-bangunan tersebut diantaranya masjid Agung Baitul Hakim yang berada di sekitar alun-alun atau pusat Kota Madiun. Berdirinya Klenteng Tri Dharma atau yang biasa disebut Klenteng Hwie Ing Kiong, yaitu tempat sembahyang orang-orang Tiong Hoa, Masjid Kuno Kuncen yang

* Annisa Tri Rahmawati adalah Alumni Mahasiswa Pendidikan Sejarah Universitas PGRI Madiun Abraham Nurcahyo adalah Dosen Pendidikan Sejarah FKIP Universitas PGRI Madiun 
berada di Kuncen dan Masjid Taman beserta makam yang bersejarah lainnya, yang merupakan salah satu bentuk peninggalan yang bersejarah yang dalam pembangunannya mempunyai makna simbolik dan filosofis tersendiri terhadap pendirian bangunan bersejarah tersebut.

Ada pula Gereja Santo Cornelius yang berada di Jalan Pahlawan Kecamatan Manguharjo Kota Madiun. Gereja Santo Cournelius Madiun yang masih berdiri hingga sekarang ini sudah sepantasnya dijaga dan dilestarikan sebagai sebuah gedung atau bangunan bersejarah, karena memang merupakan peninggalan pada masa Kolonial Belanda. Sebuah bukti sejarah yang dapat dijadikan sebab sumber sejarah sebagai penggambaran betapa besarnya kota Madiun pada masa pemerintahan Belanda waktu itu.

Gereja Santo Cornelius mempunyai kemegahan dalam bidang pengembangan arsitektur, hal ini dapat dilihat dari kontruksi bangunan yang mewah, berbeda dengan bangunan gereja kristiani dan nampak sebagai bangunan yang sederhana. Pada tanggal 27 Maret 2006, Gua Maria Santo Cornelius diresmikan. Dalam suatu bangunan gua tersebut, yang dibangun di sebelah selatan bangunan Gereja Santo Cornelius, pastinya ada suatu makna yang belum diketahui. Ada juga diatas bangunan Gereja Katolik terdapat menara tinggi yang menunjukkan suatu bangunan megah dan terdapat salip di atasnya, serta di depan bangunan terdapat patung Yesus Kristus.

Terlepas dari itu, studi sejarah berusaha untuk mendapatkan pengertian tentang sesuatu yang telah dialami termasuk yang diucapkan, dipikirkan dan dilaksanakan oleh manusia di masa lampau yang bukti-buktinya masih bisa ditelusuri atau ditemukan pada masa sekarang (Saefur Rochmat, 2009: 7).

Dengan demikian, ditinjau dari pemanfaatannya dalam konteks sejarah, hendaknya suatu bangunan dapat dijaga dan dilestarikan sebagaimana layaknya dan dapat diabadikan untuk dijadikan suatu wawasan dan potensi pada bidang religius terutama bangunan Gereja Santo Cornelius.

Gereja Santo Cournelius menjadi obyek kajian yang menarik, mengingat arsitektur bangunan yang ada di dalamnya merupakan hal yang sudah sepantasnya diketahui masyarakat umum, bahwa di Madiun masih ada sebuah bangunan yang berdiri megah sampai sekarang ini, dan merupakan sebuah bangunan peninggalan masa pemerintahan Belanda. Hal ini dipengaruhi dalam sejarah arsitektur sebagai bidang studi yang bertujuan memetakan dinamika perkembangan berbagai ragam bangunan atau lingkungan binaan dari masa ke masa, serta menguraikan keterkaitan berbagai faktor dan konteks yang memengaruhinya dalam bidang sosial, budaya, ekonomi, politik, teknologi, estetika dan lain-lain (Bagoes 
Wirjomartono,dkk, 2009: 2). Selain itu, sebuah bangunan tersebut tentu mempunyai arti atau makna dalam pembangunan gedung bersejarah. Misalnya digunakan sebagai sarana peribadatan khususnya bagi para jamaat kaum Khatolik.

Sehingga dalam sebuah bangunan bersejarah terdapat berbagai makna simbolik dan arsitektur tertentu yang selayaknya untuk dapat diketahui masyarakat umum. Kajian ini akan mengulas lebih lanjut mengenai maknamakna simbolik arsitektur yang terdapat dalam sebuah bangunan bersejarah yaitu Gereja Santo Cornelius.

Berdasarkan latar belakang masalah tersebut, maka penelitian ini dapat diorientasikan pada pemecahan masalah yang dirumuskan yaitu Bagaimanakah makna simbolik arsitektur gereja Santo Cornelius yang berada di Kelurahan Pangongangan Kecamatan Manguharjo Kota Madiun Jawa Timur?.

\section{Tinjauan Pustaka}

\section{A. Makna Simbolik}

Menurut Kamus Besar Bahasa Indonesia susunan Poerwadarminta (dalam Budiono Herusasoto 2008:17) mengartikan bahwa simbol atau lambang ialah sesuatu seperti tanda,lukisan,perkataan lencana dan sebagainya, yang menyatakan sesuatu hal yang mengandung maksud tertentu, misalnya warna putih ialah lambang kesucian, gambar padi sebagai lambang kemakmuran, atau juga berarti tanda pengenal permanen yang menyatakan sifat, keadaan dan sebagainya, misalnya tutup kepala peci merupakan tanda pengenal tutup kepala nasional Indonesia.

Dalam Kamus Logika (Dictionary of Logic) The Liang Gie menyebutkan bahwa simbol adalah tanda buatan yang bukan berwujud kata-kata untuk mewakili atau menyingkat sesuatu artian apapun (dalam Budiono Herusatoto, 2008:17-18). Tanda adalah sesuatu hal atau keadaan yang menerangkan atau memberitahukan obyek kepada subyek; sedangkan simbol atau lambang ialah sesuatu hal atau keadaan yang memimpin pemahaman si subyek kepada obyek. Tanda selalu menunjuk kepada sesuatu yang riil (nyata) yaitu benda, kejadian atau tindakan.

Kata simbol berasal dari bahasa Yunani symbolos yang berarti tanda atau ciri yang memberikan sesuatu hal kepada seseorang (Budiono Herusatoto, 2008:17). Menurut etimologinya, simbol dan simbolisasi di ambil dari kata Yunani Sumballo (sumballein) yang mempunyai beberapa arti yaitu berwawancara, merenungkan, memperbandingkan, bertemu, melemparkan menjadi satu, menyatukan.

Bentuk simbol adalah penyatuan dua hal luluh menjadi satu atau menyatukan. Dengan demikian menurut pandangan ini simbol tidak saja berdimensi horisontal-imanen, melainkan pula bermata transeden, jadi horisontal-vertikal bermatra 
metafisik. Simbol-simbol dan gambargambar merupakan jalan masuk ke dunia. Meskipun pemikiran simbolik menjadikan kenyataan yang langsung terbuka, namun pemikiran itu tidak merusak atau menggosongkan nilai kenyataan itu (Daeng, 2000:82).

Makna simbolik adalah setiap obyek atau peristiwa yang secara sosial melatar belakangi sesuatu yang lain. Simbol dapat berwujud dalam berbagai bentuk, kata-kata tertulis dan kata-kata lisan merupakan contoh paling umum dari keberadaan sebuah simbol. Selain itu, terdapat bentukbentuk komunikasi simbol dalam bentuk objek, seperti gaya rambut, cara berbusana, aksesoris, atau instrumen-instrumen lain yang berfungsi untuk mengkomunikasikan status sosial pemakainya (Fattah Hanurawan,2012:48).

Simbol merupakan alat komunikasi yang secara sosial diakui oleh manusia. Simbol sangat penting bagi kehidupan manusia karena mewakili makna yang ingin disampaikan oleh pemberi pesan kepada penerima pesan. Simbol membantu menyatukan diri manusia tindakan bersama dan memberikan arahan bagi perilaku sosial yang diterima sebagai sesuatu kesepakatan sosial atau kontrak sosial dalam suatu masyarakat tertentu (Fattah Hanurawan, 2012: 48).

Dapat ditarik kesimpulan bahwa makna simbolik adalah suatu tanda atau lambang suatu benda, keadaan atau hal yang mempunyai arti luas dan memerlukan pemahaman dalam suatu pengertian terhadap makna simbolik terhadap arsitektur bangunan.

\section{B. Arsitektur}

Istilah arsitektur dalam artian sempit,yaitu arche yang artinya utama, awal,dasar dan tekton yang artinya kestabilan, atau statistika bangunan. Dalam pengertian aslinya, Wastu (dalam Bahasa Sanskrit: Vasthu), tidak hanya berarti bangunan, tetapi segala yang terbentuk oleh tangan mausia secara menyeluruh (Romo YB Mangunwidjaya dalam Eko Budiharjo, 1991:9).

Arsitektur merupakan kristalisasi dari pandangan hidup sehingga arsitektur bukan semata-mata teknik dan estetika bangunan, atau terpecah-pecah menjadi kelompok seperti ranah keteknikan, ranah seni, atau ranah sosial. Arsitektur tidak seperti bidang seni lain, arsitektur itu sendiri hadir dalam realitas kehidupan sehari-hari. Arsitektur adalah ruang fisik atau aktivitas manusia dari satu ruang ke ruang lainnya, yang menciptakan tekanan antara ruang dalam bangunan dan ruang luar. Namun, bentuk arsitektur juga ada karena persepsi dan imajinasi manusia (Joice Marcella Laurent, 2005:26).

Alexander (dalam Joice Marcella Laurens 2005: 29) mengatakan bahwa karya arsitektur modern adalah karya yang tidak nyata, sebab dipertanyakanya apakah memang orang ingin menikmati tinggal di 
sebuah rumah kaca dan baja, atau semua itu lebih sebagai usaha untuk membuktikan bahwa ia mengerti arsitektur modern.

Dengan munculnya arsitektur post modern, meningkatlah kepedulian akan nuansa simbolis dari lingkungan binaan. Tetapi hanya ada sedikit kepedulian terhadap hal-hal kemanusiaan atau bagaimana orang mengalami makna-makna simbolis dari lingkungan sekitarnya,atau apa pentingnya makna tersebut bagi masyarakat pengguna Alexander (dalam Joice Marcella Laurens, 2005:29-30).

Arsitektur adalah pengejawantahan yang jujur dari tata cara kehidupan masyarakat dan cerminan sejarah dari suatu tempat. Kalau suatu warisan arsitektur dibongkar, lenyaplah satu babakan dalam sejarah dan putus pulalah mata rantai yang menyambungkan masa kini dan masa datang dengan masa lampau Eko Budiharjo (1991:5).

Menurut Maclaine Pont (dalam Parmono Atmadi 1993:9) arsitektur adalah bagian dari kegiatan manusia dalam menciptakan sesuatu untuk dirinya agar keluar menundukkan alam. Penekanan selain kepada kesatuan antara bentuk dan fungsi juuga pada kesatuan dengan kontruksi, sebagai perwujudan dari tradisi dalam hubungannya dengan arsitektur.

Dari beberapa pengertian tentang arsitektur, maka dapat disimpulkan bahwa arsitektur adalah hasil dari proses perancangan dan pembangunan manusia yang berdasarkan situasi, kondisi, teknologi dan seni. Arsitektur dapat dijadikan visualisasi ide-ide dari para perancangnya.

$$
\text { Memperjelas dari beberapa }
$$

pengertian arsitektur, James C. Snyder dan Anthony J. Catanese (Terjemahan Hendro Sangkoyo, 1985:39-53) mengemukakan teori tentang apakah sebenarnya arsitektur itu meliputi identifikasi variabel-variabel penting seperti ruang, struktur atau prosesproses kemasyarakatan yang dengan pengertian demikian bangunan seharusnya dinilai atau dilihat. Dalam menganjurkan cara-cara khusus untuk memandang arsitektur, ahli teori sering mendasarkan diri pada analogi-analogi sebagai berikut:

a) Analogi Matematis

Ilmu hitung dan geometri merupakan dasar penting bagi pengambilan keputusan dalam arsitektur. Arsitektur adalah permainan masa yang luar biasa, tepat dan dahsyat dalam cahaya. Mata kita diciptakan untuk melihat bentukbentuk dalam cahaya dan bayangan mengungkapkan bentuk ini seperti kubus, kerucut, bulatan,silinder atau piramida adalah bentuk primer utama yang diungkapkan cahaya hingga terlihat dengan baik dan citra benda ini jelas dan nyatadalam diri kita dan tanpa keraguan.

b) Analogi Biologis

Membangun adalah proses biologis, membangun bukanlah proses estetis. Teori-teori yang didasarkan atas analogi biologis mengambil dua bentuk. Yang 
satu sangat umum dan memusatkan perhatian pada hubungan antara bagian bangunan atau antara bangunan dan ronanya. Menurut Frank Lioyd Wright, hal ini disebut sebagai "organik". Bentuk lain dari analogi ini lebih khusus disebut "biomorfik", yaitu bentuk yang memusatkan perhatian pada proses pertumbuhan dan kemampuan pergerakan berkaitan dengan organisme.

c) Analogi Romantik

Ciri pokok dari arsitektur romantik adalah mengemban. Ia mendatangkan atau melancarkan tanggapan emosional dalam diri si pengamat. Hal ini dilakukan dengan dua cara dengan menimbulkan asosiasi atau melalui pernyataan yang dilebihkan. Bila menggunakan asosiasi, rancangan romantik akan melakukan rujukan pada alam (baik dalam bentuk rona alam maupun proses alami, seperti pembusukan), masa lalu, tempat-tempat eksotis, benda primitif, atau asosiasi masa anak-anak.

d) Analogi Linguistik

Analogi linguistik menganut pandangan bangunan dimaksudkan untuk menyampaikan informasi kepada para pengamat dengan salah satu dari tiga cara berikut ini:

1) Model Tatabahasa

Arsitektur dianggap terdiri dari unsurunsur (kata-kata) yang ditata menurut aturan (tata bahasa dan sintaksis) yang memungkinkan masyarakat dalam suatu kebudayaan tertentu, cepat memahami dan menafsirkan apa yang disampaikan oleh bangunan tersebut. Arsitektur yang baik ialah hasil dari ketaatan pada aturan-aturan, tapi itu tak berarti bahwa arsitektur yang baik dihasilkan oleh aturan yang praktis. Hal ini berarti bahwa imajinasi arsitek dan rasa artistiknya diungkapkan dalam batasbatas yang ditentukan oleh bahasa arsitektur yang universal.

2) Model Ekspresionis

Dalam hal ini bangunan dianggap sebagai suatu wahana yang digunakan arsitek untuk mengungkapkan sikapnya terhadap proyek bangunan tersebut. Bangunan dapat memberikan ulasan tentang keadaan, lokasi, masalah bagaimana menjaga agar yang luar berada di luar dan yang dalam berada di dalam, tentang masalah mendirikannya, tentang orang yang menggunakannya dan tentang orang yang membuatnya(segala hal yang dapat menjadi) lucu, sedih, dungu, diam, atau bisu.

3) Model Semiotik

Semiologi adalah ilmu tentang tanda-tanda. Penafsiran semiotik tentang arsitektur menyatakan bahwa suatu bangunan merupakan penyampaian informasi mengenai sebenarnya dan apa yang dilakukannya. Tanda-tanda saja sudah cukup untuk menyampaikan 
makna, tidak perlu untuk mencetak bangunan itu ke dalam bentuk khusus.

4) Analogi Pemecahan Masalah

Arsitektur adalah seni yang menuntut lebih banyak penalaran daripada ilham, dan lebih banyak pengetahuan faktual daripada semangat. Walaupun disebut sebagai pendekatan rasionalis, logis, sistematik, atau parametrik terhadap perancangan arsitektur. Metode pemecahan masalah beranggapan bahwa kebutuhan lingkungan merupakan masalah yang dapat diselesaikan melalui analisis seksama dan prosedur khusus.

5) Analogi Adhoci

pandangan seorang tradisionalis mengenai arsitektur akan menyatakan bahwa tugas perancang adalah memilih unsur yang layak dan membentuknya untuk memperkirakan cita-cita, pendekatan. Andhocis adalah untuk menanggapi kebutuhan langsung dengan menggunakan bahan yang mudah diperoleh dan tanpa membuat rujukan pada cita-cita. Tidak ada pedoman baku dari luar untuk mengukur rancangan tersebut. Dalam beberapa hal semua rancangan arsitektur adalah adhocis, karena kebanyakan palet si arsitek terbatas pada komponen yang ada. Rancangan adhocis sejati lebih membatasi diri, dengan menggunakan apa yang paling mudah atau yang dapat diperoleh dengan murah.
6) Analogi Bahasa Pola

Manusia secara biologis adalah serupa, dan suatu kebudayaan tertentu terdapat kesepakatan untuk perilaku dan untuk bangunan, logis untuk menyimpulkan bahwa perancangan arsitektur mungkin semata-mata merupakan tugas mengidentifikasi polapola baku kebutuhan dan pola jenis baku dari tempat untuk memuaskan kebutuhan itu. Pendekatan tipologis atau pola menganggap bahwa hubungan dan perilaku dapat dipandang dalam pengertian satuan yang digabungkan oleh perancang untuk membuat suatu bangunan atau suatu rona kota.

7) Analogi Dramaturgi

Kegiatan manusia dinyatakan sebagai teater (seluruh dunia adalah panggung) dan lingkungan buatan dapat dianggap sebagai pentas panggung. Analogi dramaturgi digunakan dengan dua cara: dari titik pandang aktor, dan dari titik pandang dramawan, dalam hal pertama arsitek menyediakan alat perlengkapan dan rona yang diperlukan untuk memainkan peranan tertentu. Penggunaan analogi dramaturgi lain ialah dari titik pandang dramawan.

Perhatian arsitek tidak banyak pada kebutuhan tokoh untuk muncul secara khusus dapat dihilangkan dari peranan seperti pengarahan gerak. Para arsitek dapat menyebabkan orang bergerak pada suatu arah atau arah yang lain 
dengan memberikan petunjuk visual. Pemanfaatan analogi dramaturgi membuat arsitek bertindak seperti dalang dan mengatur aksi seraya menunjangnya.

\section{Makna Gereja}

Gereja berasal dari kata eklesia (bahasa Yunani) yang berarti mereka yang dipanggil. Kata gereja digunakan baik untuk gedunggedung ibadah maupun untuk umat-umat Kristen maupun Katolik (Hardjana dkk,1997: 24). Dari sudut pandang Gereja sendiri merupakan perwujudan dari seruan Yesus Kristus kepada bangsa-Nya yang menginginkan mereka bertobat percaya kepada-Nya dan masuk ke dalam Kerajaan Allah. Jadi sebenarnya gereja bukan tujuan misi Yesus, melainkan sebagai sarana mengembangkan Kerajaan Allah.

Menurut Retno Sasongkowati (2013: 22) Gereja Katolik yang juga disebut Gereja Katolik Roma adalah Gereja Kristen tersebar di dunia, dan dunia mengklaim memiliki semilyar anggota, yakni kira. Gereja Katolik adalah sebuah persekutuan dari Ritus Barat (Ritus Latin) dan 22 Gereja Katolik Timur (gereja partikular) yang membentuk ribuan kauskupan di seluruh dunia. Gereja Katolik Roma adalah salah satu lembaga di dunia dan berperan penting dalam sejarah peradaban barat sejak abad ke-4.

Kerajaan Allah itu sendiri bersifat universal karena Allah adalah satu-satunya Tuhan bagi semua orang. Oleh karena itu, gereja harus mampu menjadi sarana-Nya di mana saja dan sampai akhir jaman. Usaha mewujudkan misi tersebut, sebagai manifestasi perjamuan untuk mengenang wafat dan kebangkitan Yesus bagi semua orang perlu terus diulangi dalam persaudaraan diantara murid-murid-Nya sampai ia datang kembali. Perjamuan itulah yang dalam gereja katolik disebut sebagai Liturgi Ekaristi (Hardjana dkk,1997: 91).

Liturgi Ekaristi merupakan salah satu dari liturgi-liturgi lain yang ada dalam gereja Katolik. Keseluruhan liturgi tersebut mengandung makna-makna tertentu yang semuanya mengarah pada tujuan akhir, yaitu pengembangan Kerajaan Allah di dunia. Selain itu dalam liturgi Katolik juga banyak menggunakan lambang atau tanda, baik itu verbal maupun non-verbal dan bersifat universal (sama di berbagai bangsa).

Tanda atau lambang ini yang kemudian menjadi acuan perancangan interior Gereja Katolik di dunia. Tanda-tanda itu terwujud mulai dari pola penataan layout, elemen pembentuk ruang, peletakan perabot, hingga elemen dekoratif dalam interior Gereja Katolik. Pola penataan layout Gereja katolik menggunakan bentuk yang mengarah pada tempat yang paling sakral, yaitu panti imam. Oleh sebab itu layout gereja Katolik banyak menggunakan bentuk salib yang memiliki makna, yaitu umat diajak untuk memfokuskan diri pada karya penyelamatan Allah yang dilalui dengan Jalan Salib. 
Bentuk perwujudan tanda yang lain adalah adanya perbedaan ketinggian lantai antara area umat dengan panti imam atau altar. Perbedaan ketinggian lantai ini memiliki makna peringatan umat akan bukit Kalvari tempat dimana Yesus disalibkan. Area Panti Imam terdiri atas fasilitasfasilitas, seperti altar, mimbar, sedilia, kredens, tabernakel, dan lampu Tuhan (Marcel Beding dkk, 1997:291).

Di antara fasilitas tersebut, yang paling sakral adalah Tabernakel karena merupakan tempat menyimpan Sakramen Mahakudus, yang melambangkan Tubuh Kristus. Tabernakel umumnya diletakkan di tempat yang mencolok yaitu di tengah (Marcel Beding dkk, 1997:291).Selain contoh di atas masih banyak lagi tanda liturgi yang menjadi acuan perancangan interior Gereja Katolik. Perwujudan tanda tersebut menghasilkan rancangan interior Gereja yang sejenis yang dapat dilihat dari peletakan serta penataan layout.

Liturgi merupakan bentuk doa yang menuntut perhatian istimewa dari para perencana liturgi paroki dan para pelayan liturgi. Liturgi selalu melibatkan sejumlah orang, karena liturgi adalah upacara jemaat, kegiatan suatu kelompok yang berhimpun (Gabe Huck, 2001:17). Liturgi merupakan suatu satu kesatuan yang utuh. Mengurai liturgi dan bagian-bagiannya secara terpisah akan selalu memberikan pemahaman yang tidak lengkap, sebab liturgi yang utuh jauh lebih kaya daripada semua bagian. Adapun empat unsur-unsur liturgi yaitu: kata, gerak, musik dan suasana.

Kata-kata yang biasanya digunakan dalam ritual adalah aklamasi. Aklamasi adalah kata-kata ritual yang harus dibawakan oleh setiap orang. Contoh aklamasi yang terkenal adalah Alleluya, Amin, dan Kudus. Dalam pelaksanaan upacara, aklamasi harus diserukan dengan nyaring dan hendaknya dilagukan, karena aklamasi lebih mendekati musik (Gabe Huck, 2001: 31-32).

\section{Metode Penelitian}

\section{A. Tempat Penelitian}

Penelitian ini dilaksanakan di Gereja Katolik Santo Cornelius di Kelurahan Pangongangan Kecamatan Manguharjo Kota Madiun.Pemilihan lokasi tersebut karena bangunan Gereja Katolik Santo Cornelius memiliki gaya bangunan arsitektur kolonial Belanda dengan kondisi bangunan yang cukup baik dan terawat.

\section{B. Pendekatan dan Jenis Penelitian}

Penelitian ini menggunakan pendekatan kualitatif, yang menekankan analisisnya pada proses penyimpulan deduktif dan induktif serta pada analisis terhadap dinamika hubungan antar fenomena yang diamati dengan menggunakan logika ilmiah (Saifuddin Azwar, 2004: 5). Penelitian ini diharapkan dapat menemukan fakta sejarah serta mengungkapkan berbagai informasi dengan deskripsi secara rinci dan mendalam tentang makna simbolik arsitektur Gereja 
Katolik Santo Cornelius di Kelurahan Pangongangan Kecamatan Manguharjo Kota Madiun Jawa Timur.

Jenis penelitian ini adalah penelitian sejarah atau historical research, yaitu menggunakan metode sejarah dalam pelaksanaannya. Penelitian ini bertujuan untuk membuat rekontruksi masa lampau secara obyektif dan sistematis dengan mengumpulkan, mengevaluasikan, serta menjelaskan dan mensintesiskan bukti untuk menegakkan fakta dan menarik kesimpulan secara tepat (Nazir, 2011: 48).

Daliman (2012:

menambahkan metode sejarah dibagi menjadi empat kelompok kegiatan, yakni:

a) Heuristik, ialah kegiatan menghimpun sumber-sumber sejarah.

b) Kritik (verifikasi), meneliti apakah sumber-sumber itu sejati, baik bentuk maupun isinya.

c) Interpretasi, untuk menetapkan makna dan saling-hubungan dari fakta-fakta yang telah diverifikasi.

d) Historiografi, penyajian hasil sintesis yang diperoleh dalam bentuk suatu kisaran sejarah.

\section{Sumber Data}

Sumber data adalah subjek dari mana data diperoleh (Suharsimi Arikunto, 2002: 107). Sumber data disini merupakan sumber sejarah dimana peneliti memperoleh informasi, data dan fakta sejarah. Terdapat jenis sumber data sejarah yang dapat digunakan, antara lain:

\section{Remain atau Relics}

Remain atau relics, yaitu bahanbahan fisis atau tulisan yang mempunyai nilai-nilai sejarah yang terdapat tanpa suatu kesadaran menghasilkannya untuk suatu keperluan pembuktian sejarah (Moh. Nazir, 2011:49). Suatu bukti yang otentik dari penulisan judul penelitian ini adalah makna simbolik arsitektur Gereja Katolik Santo Cornelius yang telah diperoleh sehingga dapat memberikan makna sejarah yang mudah dipahami.

\section{Sumber Data Primer}

Data primer merupakan sumbersumber dasar yang merupakan bukti-bukti atau saksi utama dalam kejadian masa lampau (Nazir, 2011: 50). Sumber data tersebut diperoleh langsung dari subjek penelitian dengan mengenakan alat pengukuran atau alat pengambilan data langsung pada subjek sebagai sumber informasi yang dicari (Saifuddin Azwar, 2004: 91).

Data primer yang dibutuhkan adalah catatan resmi, foto-foto dan hasil wawancara dari para informan yang mengetahui secara mendalam makna arsitektur Gereja Santo Cornelius di Kelurahan Pangongangan Kecamatan Manguharjo Kota Madiun Jawa Timur.

3. Sumber Data Sekunder

Data sekunder biasanya berwujud data dokumentasi atau data laporan yang telah tersedia (Saifuddin Azwar,2004:91). Sumber data sekunder penelitian ini adalah 
catatan-catatan yang tidak sezaman, bukubuku tentang sejarah arsitektur dan sumber kepustakaan lainnya.

\section{Teknik Pengumpulan Data}

Teknik pengumpulan data merupakan cara mengumpulkan data yang dibutuhkan untuk menjawab rumusan masalah penelitian (Juliansyah Noor, 2011: 138). Dalam penulisan sejarah, tahapan ini disebut sebagai heuristik yaitu tahap pengumpulan sumber-sumber sejarah oleh peneliti. Teknik pengumpulan data yang digunakan dalam hal ini adalah:

1. Wawancara

Wawancara adalah suatu kegiatan untuk mendapatkan informasi secara langsung dengan mengungkapkan pertanyaan-pertanyaan pada responden. Wawancara bermakna berhadapan langsung antara interviewer dengan responden, dan kegiatannya dilakukan secara lisan (Joko Subagyo, 2004: 39). Dalam penelitian kualitatif sebaiknya sebaiknya digunakan wawancara terbuka yang para subjeknya tahu bahwa mereka sedang diwawancarai dan mengetahui pula maksud dan tujuan wawancara itu (Lexy J. Moeloeng, 2011: 189).

Wawancara dilakukan dengan berbagai informan guna mendapatkan informasi dan data yang otentik. Pengambilan sampel informan dilakukan dengan teknik snowball sampling, mengingat sebagian informan belum diketahui secara pasti. Snowball sampling adalah teknik pengambilan sampel yang pada mulanya jumlahnya kecil tetapi makin lama makin banyak berhenti sampai informasi yang didapatkan dinilai telah cukup (Juliansyah Noor, 2011: 156).

2. Observasi

Dalam hal ini, peneliti akan melakukan observasi yang bersifat non partisipatif yaitu pengamatan yang tidak terlibat secara langsung. Adapun aspek utama yang akan diobservasi adalah :

a) Kondisi bangunan Gereja Katolik Santo Cornelius di Kelurahan Pangongangan Kecamatan Manguharjo Kota Madiun.

b) Partisipasi jamaat Gereja Santo Cornelius terhadap pelestarian bangunan Gereja.

c) Gaya arsitektur Gereja Katolik Santo Cornelius di Kelurahan Pangongangan Kecamatan Manguharjo Kota Madiun.

d) Keadaan geografis dan masyarakat Kelurahan Pangongangan

3. Dokumentasi

Dalam penelitian ini, akan berusaha mencari dokumen tentang profil Gereja Santo Cornelius Kota Madiun, data penduduk beragama Katolik, data jemaat Gereja Santo Cornelius, rencana arsitektur Gereja Santo Cornelius, gambaran bagian Gereja dan foto berkaitan makna arsitektur Gereja Santo Cornelius di Kota Madiun.

\section{E. Prosedur Penelitian}

Pelaksanaan kegiatan penelitian makna simbolik arsitektur Gereja Santo Cornelius Kota Madiun melalui beberapa tahapan. Pertama adalah menyiapkan segala 
sesuatu terhadap fenomena-fenomena yang terjadi di masyarakat Kota Madiun terhadap pengetahuan sejarah lokal Kota Madiun. Kedua,yaitu tahap pelaksanaan dengan cara mengumpulkan dan menganalisa data dengan menggunakan metode sejarah. Tahap ketiga, penyelesaian berupa interpretasi dan historiografi.

\section{F. Teknik Analisis Data}

Teknik analisis data juga menjadi bagian yang tak terpisahkan dengan interpretasi dalam metode penelitian sejarah. Menurut Sutopo (2006: 114-115) akan bergerak pada tiga komponen yaitu yaitu reduksi data, sajian data, dan penarikan kesimpulan.

\section{Hasil dan Pembahasan}

\section{A. Profil Gereja Santo Cornelius}

Gereja Santo Cornelius berada di Kelurahan Pangongangan Kecamatan Manguharjo Kota Madiun. Batas wilayah Kelurahan Pangongangan; sebelah Utara berbatasan dengan Kelurahan Madiun Lor; sebelah Selatan berbatasan dengan Kelurahan Pandean dan Nambangan Lor; sebelah Barat berbatasan dengan Kelurahan Manguharjo; sedangkan sebelah Timur berbatasan dengan Kelurahan Manguharjo (Monografi Kelurahan Pangongangan Kota Madiun).

Gereja Santo Cornelius Madiun mulai didirikan pada tanggal 12 Maret 1899, di sebelah barat Pastoran yang sekarang dipakai sebagai Aula Bernadus. Dari surat
Pastor Cornelius Stiphout, SJ pada tanggal 26 Maret 1899 dipermandikan 27 anak, dan menambah jumlah umat Katolik di Madiun, yang pada waktu itu hanya berjumlah 400 orang. Seluruh Karesidenan Madiun berpenduduk lebih dari satu juta orang, diantaranya 1.300 orang Eropa dan 4.000 orang Tionghoa. Perkembangan umat Katolik di Paroki Santo Cornelius Madiun terus meningkat, namun tidak banyak dokumen yang mencatatnya.

Pada tanggal 27 September 1982 diadakan perayaan pesta perak imanat delapan pastor CM yang sekaligus juga perayaan hari jadi Paroki Santo Cornelius. Acara ini diselenggarakan di halaman SMP Santo Yusuf Madiun. Pada tahun 1981 dimulailah pemugaran kapel Santa Maria Caruban dan pada tanggal 31 Oktober 1982, Gereja Stasi Santa Maria Caruban ini diberkati dan diresmikan. Pada bulan Desember Tahun 1988 di mulai pembangunan Gereja Stasi di Jenangan dan pada tanggal 2 April 1989, Gereja ini diberkati oleh Uskup Surabaya, Mgr Dibyokaryono dan menggunakan nama pelindung Santo Vinsensius.

Pada tahun 1989, Paroki Santo Cornelius mengembangkan pembinaan umat paroki dengan membagi daerah paroki di Kota Madiun menjadi 3 wilayah, yaitu Wilayah Timur, Wilayah Tengah dan Wilayah Barat. Adapun wilayah timur terdiri dari Lingkungan Mojorejo, Lingkungan Klegen, Lingkungan Rejomulyo, 
Lingkungan Kanigoro dan Lingkungan Santo Yusuf Klegen. Pertumbuhan umat di wilayah timur berkembang pesat seiring dibukanya beberapa perumahan di wilayah itu.

Sejak awal 1980-an, saat Pastor Paroki dijabat oleh Romo Louis Pandu, CM., mulai merencanakan pembangunan gedung gereja baru. Sebagai persiapan, maka di wilayah timur mulai menyelenggarakan kegiatan peribadatan tersendiri, khusus perayaan Natal dan Paskah. Peribadatan pertama diselenggarakan pada peringatan Paskah 1989 yang dipersembahkan oleh Romo Wignyapranoto, CM. Acara ini diselenggarakan di halaman rumah bekas poliklinik Panti Bahagija di ujung timur Jalan Slamet Riyadi. Tempat tersebut dikenal dengan Rumah Ibadah Timur.

Pada Bulan Juli 1991 mulai dibangun gedung gereja baru dan pada tanggal 6 April 1992 gedung gereja tersebut diresmikan oleh Walikota Madiun, Drs. Masdra M. Yasin dan diberkati oleh Uskup Surabaya, Mgr Dibyakaryono. Adapun gedung gereja baru tersebut diberi nama Mater Dei. Seiring berjalannya waktu maka nama wilayah timur diganti menjadi wilayah Mater Dei, yang terkoordinasi dalam wilayah $\mathrm{V}$ dan wilayah VI di dalam Paroki Santo Cornelius.

\section{B. Biografi Santo Cornelius}

Cornelius adalah seorang imam penuh kedamaian, keadilan dan kemuliaan Tuhan dengan Mahkota Kemartiran. Santo Cornelius lahir di Roma pada permulaan Abad ke-3. Bapa Paus S. Fabianuss wafat sebagai martir pada tahun 250 dalam pemerintahan Kaisar Caius. Untuk sementara tahta kepausan kosong. Kemudia, setelah damai, Imam Cornelius di Roma dipilih sebagai penggantinya pada tanggal 25 Maret Tahun.

Pada permulaan pemerintahannya, Gereja dirongrong oleh kaum bidaah yang dipimpin oleh Novasius, seorang imam yang kemudian dipilih sebagai anti Paus. Pada tahun 251 bulan April, Uskup Cartago, Siprianus sahabat Cornelius mengadakan konsili di Cartago untuk masalah tersebut. Keputusan Konsili tersebut dikuatkan oleh Sinode Roma yang dipimpin Paus Cornelius sendiri dan ia menentukan bahwa umat yang murtad dapat diterima kembali dalam Gereja asal mereka bertobat. Sinode menghukum Novisiatisme dan mengucilkan pemimpinnya.

Pada tahun 253 Kaisar Gayus Vibius Trebuniaus Gallus menangkap Cornelius dan memenjarakannya. Umatnya berbondong- bondong mengikuti ke pengadilan. Pengadilan memutuskan Paus dibuang ke Civita Vecchia tempat Bapa Paus wafat pada tahun 253. Jenazahnya kemudian dibawa kembali ke Roma dan dimakamkan di kuburan S. Siprianus. Namanya dimasukkan dalam Doa Syukur Agung Misa bersama dengan Santo Siprianus. Pestanya dirayakan pada setiap tanggal 16 September (Tondowidjojo John, 1998 : 281). 


\section{Simbolisme Arsitektur Gereja Katolik Santo Cornelius}

Gereja Katolik Santo Cornelius berada di wilayah Kota Madiun, dibangun dengan menara dan salib di atas atapnya seperti bangunan Gereja Katolik pada umumnya. Dinamakan Gereja Santo Cornelius, karena Cornelius adalah seorang imam yang bijaksana, saleh dan seorang imam penuh kedamaian, keadilan dan kemuliaan Tuhan dengan Mahkota Kemartiran. Oleh karena itu, sebagai umat Katolik menamakan Gereja tersebut dengan nama Gereja Santo Cornelius.

Tanggal 27 November 2006, Gua Maria yang berada di halaman selatan gereja diresmikan dan diberkati oleh Administrator Keuskupan Surabaya, Romo Yulius Haryanto, CM. Gereja Santo Cornelius ini dirancang untuk umum, karena Katolik sendiri berarti umum. Tabernakel dilengkapi dengan lampu yang menyala terus sebagai simbol Yesus Kristus cahaya abadi.

Itu sebabnya, ketika orang masuk ke gereja, biasanya didahului dengan pengambilan air suci di depan pintu masuk lalu melakukan tanda salib dan seterusnya bersujud. Sujud bukan bermaksud menghormati orang di dalam Gereja, bukan menghormati salib dan patung-patung dalam gereja. Sujud atau berlutut itu menunjukkan sikap hormat dan sembah sujud kepada Allah atau Yesus sendiri yang sungguh hadir dalam gereja tersebut yang ditandai dengan tabernakel. Di depan Tabernakel, terdapat altar tempat mempersembahkan perayaan Ekaristi.

Di samping kanan altar terdapat mimbar untuk membaca Kitab Suci yang letaknya lebih tinggi dari mimbar sebelah kiri untuk membaca doa atau pengumuman penting lainnya. Mimbar sebelah kanan sengaja diletakkan lebih tinggi, karena merupakan tempat membaca Sabda atau Firman Tuhan atau mimbar untuk Tuhan. Allah hadir dalam pembacaan Sabda-Nya oleh para romo, frater, atau lektor/lektris dan pemazmur, sebab mazmur termasuk Firman Allah sendiri. Mimbar sebelah kanan tersebut, sama dengan altar, sehingga hendaknya tidak digunakan sembarangan.

Kalau ada pengumuman penting atau sekedar latihan, sebaiknya menggunakan mimbar sebelah kiri yang letaknya lebih rendah. Di samping kiri mimbar, ada patung Bunda Maria .Karena itu, umat sering berdoa kepada Yesus melalui perantaraan Bunda Maria dengan memandangi patung tersebut.

Keunikannya adalah posisi menara yang berada di sebelah kiri pintu masuk. Hampir semua bangunan gereja dengan satu menara, tata bentuknya menempatkan menara di sebelah kiri pintu masuk. Secara psikologis posisi di sebelah kiri pintu masuk memberi rasa aman mengingat manusia selalu merasa lemah di sebelah kiri. Keberadaan suatu benda yang tinggi dan 
menjulang di sebelah kirinya akan memberi rasa aman.

Makna simbolis dari penempatan menara di sisi kiri adalah Allah yang melindungi manusia dengan tangan kananNya (apabila dilihat posisi altar atau mimbar adalah posisi di mana Allah hadir dan memandang ke arah masuk umat, maka menara merupakan tangan kanan Allah). Jadi peran menara adalah sebagai tanda perlindungan Ilahi bagi umat.

Desain interior gereja Katolik adalah proses penataan interior suatu tempat ibadah dengan mengacu pada liturgi Katolik serta bertujuan untuk mendukung aktivitas umat dalam berliturgi. Fungsi liturgi dalam Gereja tersebut adalah untuk memfokuskan ibadat dengan menggunakan simbol-simbol untuk membantu umat beriman menghayati imannya, baik secara pribadi maupun bersama-sama sebagai Sebagai contoh, dalam liturgi abumempunyai makna mengingatkan kefanaan yang akan dihadapi oleh semua orang.

Makna tanda liturgi Katolik dapat diwujudkan dalam pola serta penataan dalam interior Gereja Katolik. Unsur-unsur desain interior dalam Gereja Katolik yang mempunyai pola serta penataan terkait dengan makna tanda liturgi adalah layout, elemen pembentuk ruang, perabot, dan warna. Seluruh unsur di atas yang menjadi perwujudan tanda liturgi akan ditelusuri maknanya berdasarkan acuan liturgi. Dan diuraikan seluruh unsur fisik ruang yang dapat dijelaskan kesesuaiannya sebagai tanda yang menyimbolkan ketiga makna tersebut dan dengan nilai-nilai tanda sesuai dengan perwujudan-nya, yaitu perwujudan sesuai nilai-nilai yang terkandung dalam unsur-unsur nirmana.

Perlengkapan liturgi, yaitu perabot dan unsur dekoratif lainnya akan dibahas mengenai fungsi dan tujuannya maupun peletakannya. Hal-hal yang terkait dengan liturgi mengenai perlengkapannya antara lain perlengkapan yang ada di area mahakudus dan perlengkapan yang ada di area jemaat. Perlengkapan liturgi yang ada di area maha kudus, meliputi meja altar, mimbar, kursi imam, kursi petugas liturgi, salib, dan lilin. Perlengkapan liturgi yang ada di area jemaat, antara lain kursi jemaat, kursi paduan suara.

Letak meja altar dalam Gereja Katolik Santo Cornelius Kota Madiun relevan dengan makna liturgi, yaitu di tengah ruang mahakudus sehingga mudah dilihat oleh jemaat. Peletakan seperti ini sangat menunjang penghayatan jemaat saat terjadi pemecahan roti di atas meja perjamuan. Bila dikaji secara kaidah nirmana, maka letak meja altar di tengah ruang mahakudus menjadi pusat perhatian umat. Bila dikaitkan dengan unsur-unsur semiotik, diperoleh nilai sebagai berikut:

1. Nilai denotatif: meja altar sebagai pusat dari ruang gereja sehingga mudah dilihat oleh umat. 
2. Nilai konotatif: umat dapat lebih menghayati pengorbanan Kristus dengan menyaksikan dengan jelas peristiwa pemecahan roti.

Peletakan meja sabda di Gereja Katolik Santo Cornelius Kota Madiun berdekatan dengan meja altar, yaitu di ruang mahakudus. Peletakan ini sesuai dengan filosofi liturgi, dimana meja altar harus selalu berdekatan dengan meja sabda karena Liturgi Sabda dan Liturgi Ekaristi saling berkaitan. Bila dikaji secara kaidah nirmana dan dikaitkan dengan unsur semiotik, diperoleh nilai-nilai sebagai berikut:

1. Nilai denotatif: sebagai tempat membacakan sabda sebelum peristiwa pemecahan roti.

2. Nilai konotatif: pembacaan sabda mendukung peristiwa pemecahan roti.

Tabernakel di Gereja Katolik Santo Cornelius Kota Madiun ditanam di dinding tengah altar. Apabila tabernakel diletakkan di dinding tengah area maha kudus, maka posisinya akan terhalang oleh pastor sehingga tidak mudah dilihat umat. Selain itu pastor paroki juga berpendapat bahwa Tubuh Kristus yang ada dalam tabernakel harus dihormati sehingga tidak etis apabila ia membelakangi tabernakel. Oleh karena itu diputuskan tabernakel diletakkan di sebelah kiri altar agar lebih mudah dilihat oleh umat. Peletakan tabernakel ini walaupun berbeda dengan di gereja-gereja pada umumnya, namun tetap memenuhi makna liturgi.

Ada beberapa buah lilin di ruang mahakudus Gereja Santo Cornelius. Lilin tersebut ditempatkan di tempat khusus yang dapat berdiri sendiri dan diletakkan di samping meja altar. Diletakkan dekat meja altar karena berkaitan dengan kurban Kristus yang diperingati melalui pemecahan roti di atas meja perjamuan (meja altar). Letak kursi jemaat dari belakang hingga depan semakin menurun mengikuti penurunan lantai yang ada.

Peletakan kursi jemaat dalam Gereja Santo Cornelius Kota Madiun ini relevan dengan makna liturgi Katolik karena dengna letak kursi seperti itu menjadi tanda kesatuan antara jemaat dengan Imam dan antar jemaat yang duduk. Kursi paduan suara berkapasitas \pm 30 orang, diletakkan di area ruang berhimpun, yaitu di bagian kiri ruang mahakudus. Kursi paduan suara ini letaknya tidak terpisah dengan ruang jemaat. Hal ini menjadi tanda partisipasi umat dengan jemaat lain sehingga mendukung jalannya Perayaan Ekaristi.

Wujud fisik interior Gereja Katolik Cornelius Kota Madiun ditinjau dari sudut nirmana merupakan salah satu wujud dari nilai-nilai Liturgi Katolik (Arsip Gereja Santo Cornelius). Oleh karena itu setiap unsur seharusnya disesuaikan dengan makna liturgi, walaupun dengan persepsi-persepsi yang berbeda baik dari pihak arsitek maupun pastor paroki. Liturgi menjadi 
dasar perancangan interior sebuah gereja katolik, walaupun dengan berbagai persepsi dalam menerjemahkan makna liturgi tersebut, pada Gereja Katolik Santo Cornelius Kota Madiun menunjukkan:

1. Ada perwujudan fisik interior yang memiliki nilai semiotik dari makna liturgi sehingga baik secara denotatif dan konotatif harus mencerminkan makna liturgi. Hal ini dikarenakan wujud tersebut memang merupakan simbol yang mencirikan kegiatan berliturgi.

2. Perwujudan yang berbeda tetapi secara semiotik masih mencerminkan makna liturgi. Hal ini dikarenakan wujud tersebut bukan menjadi simbol yang paling mencirikan kegiatan berliturgi.

3. Perwujudan fisik interior yang berbeda dan memiliki nilai semiotik (denotatif dan konotatif) yang tidak sesuai dengan makna liturgi. Hal ini dibuat dengan pertimbangan wujud tersebut menjadi simbol adaptasi dan kefleksibelan Gereja Katolik terhadap lingkungannya sehingga akhirnya menunjang kegiatan berliturgi.

Untuk menandai masa-masa dan perayaan-perayaan atau pesta-pesta tertentu, Gereja mempergunakan warnawarna tertentu yang disebut dengan warna Liturgi. Adapun warna-warna yang dipakai dan makna-maknanya adalah sebagai berikut :

1. Putih: lambang kegembiraan, kesucian,kemurnian. Dipakai hari raya atau pesta Tuhan Yesus Kristus, Ibu
Maria, para Malaikat, dan pria atau wanita kudus.

2. Merah: lambang cinta kasih, api, darah, kekuatan, dan Roh Kudus. Dipakai pada hari raya Minggu Palma, Jumat Agung, Pentakosta, dan pesta para Martir.

3. Hijau: lambang harapan, syukur dan kesuburan. Dipakai pada masa biasa

4. Ungu: lambang tobat, mati raga, kesedihan, keprihatinan. Dipakai pada masa Adven dan Pra paskah, sering juga pada misa arwah.

5. Hitam: lambang duka, dan berkabung. Dipakai untuk misa arwah dan penguburan.

6. Kuning Emas: lambang kemuliaan. Pemakaiannya seperti pada warna putih.

Warna-warna liturgi tersebut dapat dilihat pada pakaian imam ketika mempersembahkan misa, khususnya stola (selempang) dan kasula (pakaian paling luar) (Hardjana dkk, 1997: 61-62). Menara dalam bangunan gereja memiliki muatan simbolik sebagai suatu peringatan dan undangan bagi umat untuk datang beribadah.

Apalagi dengan dilengkapi oleh keberadaan lonceng yang kerap digunakan dalam perayaan tertentu Gereja Katolik Santo Cornelius, pada umumnya seperti dengan Gereja Katolik lainnya, setiap jamjam tertentu lonceng Gereja dibunyikan, setiap pagi pada pukul 06.00 WIB, setiap siang jam $12.00 \mathrm{WIB}$, dan setiap sorenya dibunyikan pada jam 18.00 WIB, dan pada 
saat diluar itu berarti tanda jam misa. Tujuan dibunyikan lonceng adalah untuk mengajak umat berdoa ke Malaikat Tuhan.

Tatanan massa berbentuk salib bukanlah hal baru dalam desain gereja. Bagi gereja-gereja tua atau klasik, bentuk salib adalah bentuk yang paling umum. Salib merupakan simbol identitas kristiani. Salib mengingatkan umat kristiani tentang pengorbanan Kristus dan penyelamatan manusia. Kematian Kristus di salib adalah sebuah wujud nyata kasih dalam pengorbanan diri Kristus demi menyelamatkan manusia.

Salib juga merupakan simbol kemenangan dari dosa. Karena peristiwa penyaliban Kristus, umat manusia diselamatkan dari dosa (menang dari dosa). Salib juga mengingatkan umat Kristiani untuk meninggalkan hidup keduniawian dan senantiasa berbalik kepada Tuhan.

\section{Penutup}

\section{A. Kesimpulan}

Gereja Katolik Santo Cornelius berada di wilayah Kota Madiun, dibangun dengan menara dan salib di atas atapnya seperti bangunan Gereja Katolik pada umumnya. Dinamakan Gereja Santo Cornelius, karena Cornelius adalah seorang imam yang bijaksana, saleh dan seorang imam penuh kedamaian, keadilan dan kemuliaan Tuhan dengan Mahkota Kemartiran. Kerena hal tersebut, sebagai umat Katolik menamakan Gereja tersebut dengan nama Gereja Santo Cornelius.

Tabernakel dilengkapi dengan lampu yang menyala terus sebagai simbol Yesus Kristus cahaya abadi. Itu sebabnya, ketika orang masuk ke gereja, biasanya didahului dengan pengambilan air suci di depan pintu masuk lalu melakukan tanda salib dan seterusnya bersujud.

Sujud itu bukan bermaksud menghormati orang-orang di dalam Gereja, bukan menghormati salib dan patungpatung dalam gereja. Sujud atau berlutut itu menunjukkan sikap hormat dan sembah sujud kepada Allah atau Yesus sendiri yang sungguh hadir dalam gereja tersebut yang ditandai dengan tabernakel.

Di depan Tabernakel, terdapat altar tempat mempersembahkan perayaan Ekaristi.bentuk ruang adalah lantai sebagai tempat perabot diletakkan dan tempat berlangsungnya kegiatan ibadat. dinding sebagai tempat sumber sirkulasi, yaitu pintu, sebagai sirkulasi manusia dan jendela, sebagai sirkulasi udara, cahaya, dan suara, serta sebagai penutup kegiatan yang ada di dalam ruang. Elemen pembentuk ruang yang ketiga adalah plafon yang memberi perlindungan area yang di bawahnya maupun memberi kesan menekan bila plafon rendah dan kesan agung bila plafon tinggi.

Keunikannya adalah posisi menara yang berada di sebelah kiri pintu masuk. Secara psikologis posisi di sebelah kiri pintu 
masuk memberi rasa aman mengingat manusia selalu lemah di sebelah kiri.

Makna simbolis penempatan menara di sisi kiri adalah Allah yang melindungi manusia dengan tangan kanan-Nya. Jadi peran menara adalah sebagai tanda perlindungan Ilahi bagi umat.

\section{B. Saran}

Berdasarkan kesimpulan diatas maka terdapat saran-saran sebagai berikut:

1. Pemerintah Kota Madiun:agar ikut serta dalam menjaga tempat peribadatan khususnya Gereja Santo Cornelius yang berada di Kota Madiun sebagai bangunan yang mempunyai makna nilai-nilai sejarah di masa Kolonial Belanda.

2. Pengelola Balai Paroki Gereja Santo Cornelius: agar terus menjaga dan merawat bangunan bersejarah pada masa Kolonial Belanda ini, dan sebagai wujud pelestarian bangunan bersejarah yang ada di Kota Madiun.

3. Penelitian selanjutnya dengan tema yang sama supaya menganalisis dengan kajian yang berbeda.

\section{Daftar Pustaka}

A. Daliman. 2012. Metode Penelitian Sejarah. Yogyakarta: Ombak.

Bagoes Wirjomartono, dkk. 2009. Sejarah Kebudayaan Indonesia: Arsitektur. Jakarta: PT. RajaGrafindo Persada.

Budiono Herusatoto. 2008. Simbolisme Jawa. Yogyakarta: Ombak.

Eko Budiharjo. 1991. Arsitektur dan Kota di Indonesia. Bandung: Penerbit Alumni Anggota IKAPI.
Fattah Hanurawan. 2012. Psikologi Sosial: Suatu Pengantar. Bandung: PT Remaja Rosdakarya Offset.

Francis D.K. Ching. 2000. Arsitektur: Bentuk, Ruang, dan Tatanan. Jakarta: Erlangga.

Gabe Huck. 2001. Liturgi yang Anggun dan Menawan. Yogyakarta: Kanisius.

H. B. Sutopo. 2006. Metodologi Penelitian Kualitatif. Surakarta: Universitas Sebelas Maret.

Hans J. Daeng. 2000. Manusia, Kebudayaan dan Lingkungan Tinjauan Antropologis. Yogyakarta: Pustaka Pelajar (Anggota IKAPI).

Hardjana, dkk. 1997. Mengikuti Yesus Kristus 2. Yogyakarta: Kanisius.

James C. Snyder, dkk . 1985. Pengantar Arsitektur. Terjemahan Hendro Sangkoyo. Jakarta: Erlangga.

Joko Subagyo. 2004. Metode Penelitian Dalam Teori dan Praktek. Jakarta : PT Asdi Mahasatya.

John Tondowidjojo C.M. 1998. Pertumbuhan dan Perkembangan Cornelius Madiun 1897-1997. Surabaya: Yayasan Sanggar Bina Tama.

Joyce Marcella Laurens. 2004. Arsitektur dan Perilaku Manusia. Jakarta: PT Grasindo.

Juliansyah Noor. 2011. Metodologi Penelitian: Skripsi, Tesis, Disertasi dan Karya Ilmiah. Jakarta: Kencana

Lexy. Moleong. 2011. Metodologi Penelitian Kualitatif. Bandung: PT Remaja Rosdakarya.

Marcel Beding, dkk. 1997. Gereja Indonesia Pasca-Vatikan II Refleksi dan Tantangan. Yogyakarta: Kanisius.

Moh Nazir. 2011. Metode Penelitian. Bogor : Ghalia Indonesia.

Parmono Atmadi. 1988. Arsitektur Kolonial Belanda di Indonesia. Yogyakarta : Gadjah Mada University Press.

R.Sutrisno. 1983. Bentuk Struktur Bangunan dalam Arsitektur Modern. Jakarta : PT Gramedia. 
Retno Sasongkowati. 2002. Ensiklopedia Sejarah Dunia Termutakhir. Depok : Lamafa Publika.

Saefur Rochmat. 2009. Ilmu Sejarah Dalam Perspektif Ilmu Sosial. Yogyakarta : Graha Imu.

Saifuddin Azwar. 2004. Metode Penelitian. Yogyakarta: Pustaka Pelajar.

Sugiyono. 2014. Memahami Penelitian Kualitatif. Bandung : Alfabeta.

Suharsimi Arikunto. 2002. Prosedur Penelitian Suatu Pendekatan Praktek. Jakarta: PT Rineka Cipta 